\title{
Learning Styles of Premedical and Basic Science Undergraduate Medical Students in a Caribbean Medical School
}

\section{P. Ravi Shankar, Ramanan Balasubramanium, Neelam R Dwivedi, Ravi Ramireddy, Byron Barton}

Xavier University School of Medicine, \# 23, Santa Helenastraat, Madiki, Oranjestad, Aruba, Kingdom of the Netherlands

\section{ARTICLE INFO}

$\begin{array}{ll}\text { Received } & : 10 / 01 / 2014 \\ \text { Accepted } & : 11 / 05 / 2014 \\ \text { Published } & : 01 / 09 / 2014\end{array}$

\section{KEYWORD}

Learning styles

Medical students

Teaching

VARK questionnaire

\section{ABSTRACT}

Introduction: Xavier University School of Medicine, Aruba admits students from the United States, Canada to the undergraduate medical (MD) course. Learning styles have not been previously studied in the institution. Objective: The present study was carried out to study the learning styles of students and note the association of these with their demographic characteristics, if any among first to fourth semester premedical students and first to fourth semester undergraduate medical (MD) students during November 2013. Method: Version 7.2 of the VARK questionnaire was used. Age, gender, semester of study and nationality of the respondents were noted. The mean scores among different subgroups of respondents were compared using appropriate statistical tests $(\mathrm{p}<0.05)$. Result: Ninetyone of the 108 students $(84.26 \%)$ completed the questionnaire. The median visual, auditory, read-write and kinaesthetic scores were 3, 5, 4 and 5 respectively. The median auditory score was significantly higher among Premedical 2 and 4 students. Forty-three respondents (47.2\%) preferred a unimodal learning style while $48(52.7 \%)$ used multiple learning styles. Conclusion: The most preferred learning style was kinaesthetic followed by auditory and read and write. More small group sessions and active learning can be used to cater to these students.

(c) Medical Education Department, School of Medical Sciences, Universiti Sains Malaysia. All rights reserved.

CORRESPONDING AUTHOR: Dr. P Ravi Shankar, Xavier University School of Medicine, \#23, Santa Helenastraat, Oranjestad, Aruba. Email: ravi.dr.shankar@gmail.com

\section{Introduction}

Learning style of students has been defined as the manner in which and the conditions under which learners most efficiently and effectively perceive, process, store and recall what they are attempting to learn [1]. Learning styles vary among individuals and have been classified into four main categories, visual, auditory, read-write and kinaesthetic (VARK). Visual learners have a preference for seeing or visualizing, auditory learners prefer learning through listening, readwrite learners learn best by reading and writing words while kinaesthetic learners learn best by doing [1]. Differences in learning styles among undergraduate medical students have been confirmed in a number of studies [2-5].

The VARK questionnaire was developed by Neil Fleming of Christchurch, New Zealand and is 
available online [6]. The instrument has been used in a number of studies and settings to assess the learning styles of students. Understanding the learning style of students can help curriculum planners design and implement learning activities which can lead to more effective student learning. Student motivation and performance improves when instruction is adapted to their learning styles [7]. As students have a diversity of learning styles the instructor has the responsibility to address this diversity and develop appropriate learning styles [8]. Although students may use a variety of sensory modalities for learning there may be a stronger preference for a particular modality. The first preference is the modality which obtains the highest score while depending on the distribution among the four sensory modalities there may be unimodal and multimodal students.

Xavier University School of Medicine is a private medical school in Aruba admitting students from the United States (US), Canada and other countries to the undergraduate medical (MD) course. Students complete the first four semesters of the course at Xavier University School of Medicine (XUSOM) and then complete their clinical rotations in the US. At XUSOM each semester is of 15 weeks duration and three batches of students are admitted every year in January, May and September. The school also offers a premedical program for students who have completed high school which consists of four semesters each of 15 weeks duration similar to the MD program. Recently the school has shifted to an integrated, organ system-based curriculum and problem-based learning and small group learning strategies have been introduced [9]. Despite the changes didactic lectures continue to be the dominant teaching method. Learning styles among premedical and medical students in the institution have not been previously studied. Hence the present study was conducted to study the learning styles of students and note the association of these with their demographic characteristics, if any.

\section{Method}

The study was conducted among first to fourth semester premedical students and first to fourth semester undergraduate medical (MD) students during November 2013. The latest version of the VARK questionnaire (version 7.2) was used to study the learning styles of students after obtaining written permission from the developer [6]. Demographic characteristics (age, gender, semester of study and nationality) were noted. Students were informed about the study and invited to participate. Those students who wanted personal feedback about their learning styles were instructed to also fill in their names. Written informed consent was obtained from all participants. The study was approved by the Institutional Review Board of the institution vide notification XUSOM/IRB/2013/09.

The completed questionnaires were scored using instructions available on the VARK website. The demographic details were coded and entered in the Statistical Package for Social Sciences (SPSS) version 20 for Windows. The visual, auditory, read and write and kinaesthetic scores for each respondent were also entered. The normality of distribution of these variables were determined using the one sample KolmogorovSmirnov test $(\mathrm{p}<0.05)$. The average scores among different categories of respondents were compared using appropriate statistical tests $(\mathrm{p}<0.05)$.

According to the distribution of scores among the four learning styles respondents were classified into unimodal and multimodal learning styles.

\section{Result}

Ninety-one of the 108 students (84.26\%) completed the questionnaire. Table 1 shows the demographic characteristics of the respondents. The scores of individual respondents for the four learning styles did not follow a normal distribution and hence median was used as the measure of central tendency. 
Table 1: Demographic characteristics of the respondents*

\begin{tabular}{llc}
\hline \multicolumn{1}{c}{ Characteristic } & Number (percentage) \\
\hline Semester & Premedical 1 & $16(17.6)$ \\
& Premedical 2 & $3(3.3)$ \\
& Premedical 3 & $6(6.6)$ \\
& Premedical 4 & $3(3.3)$ \\
& MD 1 & $13(14.3)$ \\
& MD 2 & $15(16.5)$ \\
& MD 3 & $20(22)$ \\
& MD 4 & $15(16.5)$ \\
\hline Gender & Male & $56(61.5)$ \\
& Female & $35(38.5)$ \\
\hline Age (years) & Less than 20 & $23(25.3)$ \\
& 20-25 & $43(47.3)$ \\
& More than 25 & $24(26.4)$ \\
\hline Nationality & American & $36(39.6)$ \\
& Canadian & $13(14.3)$ \\
& Others & $42(46.2)$ \\
\hline * The total may & not add up to 91 as certain respondents did not complete
\end{tabular}

The median visual, auditory, read-write and kinaesthetic scores were $3,5,4$ and 5 respectively. Table 2 shows the median scores among different subgroups of respondents. The median auditory score was significantly higher among the Premedical 2 and Premedical 4 students compared to other semesters. There were no other significant differences in scores among other subgroups of respondents.

* The total may not add up to 91 as certain respondents did not complete all the required details

Table 2: Median scores of different learning styles among various subgroups of respondents

\begin{tabular}{|c|c|c|c|c|c|c|c|c|}
\hline Characteristic & $\begin{array}{c}\text { Median } \\
\text { visual } \\
\text { score } \\
\end{array}$ & $P$ value & $\begin{array}{c}\text { Median } \\
\text { auditory } \\
\text { score } \\
\end{array}$ & $P$ value & $\begin{array}{c}\text { Median } \\
\text { read and } \\
\text { write score } \\
\end{array}$ & $P$ value & $\begin{array}{c}\text { Median } \\
\text { kinaesthetic } \\
\text { score } \\
\end{array}$ & $P$ value \\
\hline Semester & & 0.415 & & 0.034 & & 0.957 & & 0.859 \\
\hline Premedical 1 & 3 & & 5 & & 4.5 & & 4 & \\
\hline Premedical 2 & 3 & & 6 & & 3 & & 5 & \\
\hline Premedical 3 & 2.5 & & 4.5 & & 4 & & 4.5 & \\
\hline Premedical 4 & 6 & & 6 & & 4 & & 7 & \\
\hline MD 1 & 3 & & 5 & & 4 & & 5 & \\
\hline MD 2 & 3 & & 4 & & 5 & & 4 & \\
\hline MD 3 & 3 & & 3 & & 4 & & 5 & \\
\hline MD 4 & 3 & & 4 & & 3 & & 5 & \\
\hline Gender & & 0.280 & & 0.900 & & 0.960 & & 0.715 \\
\hline Male & 3 & & 4.5 & & 4 & & 5 & \\
\hline Female & 3 & & 5 & & 4 & & 5 & \\
\hline Age & & 0492 & & 0.558 & & 0.464 & & 0.386 \\
\hline$<25$ years & 3 & & 5 & & 5 & & 5 & \\
\hline $20-25$ years & 3 & & 4 & & 4 & & 4 & \\
\hline$>25$ years & 3 & & 4 & & 4.5 & & 5 & \\
\hline Nationality & & 0.778 & & 0.593 & & 0.576 & & 0.669 \\
\hline US & 3 & & 4 & & 4 & & 4 & \\
\hline Canadian & 3 & & 4 & & 4 & & 5 & \\
\hline Others & 3 & & 5 & & 4 & & 5 & \\
\hline
\end{tabular}

Table 3 shows the preferred learning styles of different respondents. The distribution was nearly equal between preference for unimodal and multimodal learning styles. The most preferred learning style was kinaesthetic followed by auditory and read and write. Among the most preferred multimodal learning styles were the combination of auditory, read and write and kinaesthetic (ARK), auditory and kinaesthetic and read and write and kinaesthetic.
Table 3: Frequency of different learning styles among the respondents

\begin{tabular}{lc}
\hline Learning style & Number (percentage) \\
\hline Unimodal & $43(47.2)$ \\
Kinaesthetic & $16(17.6)$ \\
Auditory & $12(13.2)$ \\
Read and write & $12(13.2)$ \\
Visual & $3(3.3)$ \\
\hline Multimodal & $48(52.7)$ \\
ARK & $9(9.9)$ \\
AK & $9(9.9)$ \\
RK & $7(7.7)$ \\
VRK & $5(5.5)$ \\
AR & $5(5.5)$ \\
VAR & $3(3.3)$ \\
VK & $3(3.3)$ \\
VARK & $2(2.2)$ \\
VA & $2(2.2)$ \\
VR & $2(2.2)$ \\
VAK & $1(1.1)$ \\
\hline V= visual, A= aural/auditory, $\mathrm{R}=$ read and write, $\mathrm{K}=$ Kinaesthetic
\end{tabular}




\section{Discussion}

The number of students who used unimodal and multimodal learning styles were approximately equal. A large number of students preferred a kinaesthetic learning style. The median scores for an auditory learning style were significantly higher among Premedical 2 and Premedical 4 students.

In a study conducted in a medical school in Michigan, United States $63.8 \%$ of students preferred multiple modes of information presentation and among the unimodal learning styles kinaesthetic was most preferred [1]. The authors concluded that most students would benefit more from a greater use of active learning strategies and most were able to learn effectively provided the teacher provided a blend of learning activities. In a study conducted in a medical school in Chile it was found that preference for a particular learning style did not affect student performance in multiple choice questions (MCQs) [10]. In another study conducted in a medical school in Michigan, US it was found both male and female students preferred multiple modes of information presentation and the number and types of combinations used were not significantly different among the genders [11]. However female students used a greater combination of learning style and tended to be more diverse. The authors of that article state that the VARK questionnaire can serve as a tool for reflection for both instructors and students. Students can gain awareness about their preferred learning style which can help them adjust their learning behaviour to take advantage of their strengths and weaknesses. For visual (V) learners presenters who use gestures and picturesque language may be helpful [12]. Use of flow charts, pictures, posters and slides, graphs and underlining books and reading material with different coloured highlighters would be useful. For auditory (A) learners it has been recommended to attend all classes, discuss topics with others, explain ideas to others, use a tape recorder and put summarized notes onto tapes and listen to them [13]. Kinaesthetic (K) learners should learn using all the different modalities of information gathering, benefit from lecturers who provide real life experiences, learn from applications and hands on experiences and may require to role play the exam situation in their room [14]. Instructors can adjust their teaching and information delivery to be in consonance with the learning styles of their class

In a dental college in Saudi Arabia, students with a single learning style preference had a lower grade point average (GPA) compared to those who employed multiple learning styles [15]. The authors also concluded that for more effective instruction dental educators may need to broaden their range of presentation styles. A similar result was noted in another study conducted in a Saudi medical school where the dominant learning style of students was found to be multimodal [16]. Female students again showed more diverse preferences compared to males and students with a higher GPA showed a preference for multimodal learning. In a medical school in India appreciative enquiry was used to help students discover learning strategies that would be effective for different individual learning styles and discussion within student groups helped them identify strategies to overcome limitations of the school's teaching methods [5].

At Xavier University School of Medicine like in other Caribbean medical schools didactic lectures continues to be the predominant teaching method. Recently however other small group active learning strategies like small group discussions, PBL sessions and role-plays have been introduced. A large percentage of students had a preference for kinaesthetic learning strategies which may require more practical sessions and small group activity-based sessions to be incorporated in the curriculum. The results of this preliminary study can help teachers identify the predominant learning strategies employed by students and can help improve teaching-learning.

The study had limitations. The VARK questionnaire measures and analyzes only one aspect of the student learning style. Information was collected only using the questionnaire and was not triangulated with other methods. The 
correlation between student learning styles and academic performance was not studied.

\section{Conclusion}

Students at Xavier University School of Medicine used a variety of learning styles. Premedical 2 and 4 students had higher auditory learning scores. No other significant differences in scores among various subgroups of students were seen. A large number of students used kinaesthetic learning either alone or in combination with other learning styles. Understanding student learning styles can make teaching-learning more effective. Similar studies are required in other Caribbean medical schools.

\section{Acknowledgment}

The authors acknowledge the constant support of the Dean of Basic Sciences, Xavier University School of Medicine, Aruba. They thank the Information Technology director, Mr. Barry Adunmo for his support. They are grateful to Ms. Liza Koolman, Administrative Assistant for entering the data in SPSS. They thank all students who participated in the study. They are grateful to Mr. Neil Fleming, Director, VARK Learn Limited, Christchurch, New Zealand for providing them permission to use the VARK questionnaire for this study.

\section{Reference}

1. Lujan HL, DiCarlo SE. First-year medical students prefer multiple learning styles. Adv Physiol Educ. 2006;30:13-16.

2. Dobson JL. A comparison between learning style preferences and sex, status, and course performance. Adv Physiol Educ. 2010;34:197-204.

3. Buali WH, Balaha MH, Muhaidab NS. Assessment of learning style in a sample of Saudi medical students. Acta Inform Med. 2013;21:83-88.

4. Kharb P, Samanta PP, Jindal M, Singh V. The learning styles and the preferred teaching-learning strategies of first year medical students. J Clin Diagn Res. 2013;7:1089-1092.
5. Kumar LR, Chacko TV. Using appreciative inquiry to help students identify strategies to overcome handicaps of their learning styles. Educ Health (Abingdon). 2012;25:160-164.

6. Fleming $\mathrm{N}$. The VARK questionnaire version 7.2. Available from: http://www.varklearn.com/documents/the\%20vark\%20questi onnaire.pdf [Last accessed on 2014 January 5].

7. Miller P. Learning styles: the multimedia of the mind. Educational Resources Information Center ED 451 140, 2001.

8. Tanner K, Allen D. Approaches to biology teaching and learning: learning styles and the problem of instructional selectionengaging all students in science courses. Cell Biol Educ. 2004;3:197-201.

9. Shankar P, Dubey AK. 'Modernizing' the Basic Sciences MD program at XUSOM, Aruba. WebmedCentral Medical Education. 2013;4(4):WMC004198.

10. Ramirez BU. The sensory modality used for learning affects grades. Adv Physiol Educ. 2011;35:270-274.

11. Slater JA, Lujan HL, DiCarlo SE. Does gender influence learning style prefere nces of first-year medical students? Adv Physiol Educ. 2007;31:336-342.

12. Visual study strategies. http://www.varklearn.com/english/page.asp?p=visual. [Last accessed on 2013 December 30].

13. Aural study strategies. http://www.varklearn.com/english/page.asp?p=aural [Last accessed on 2013 December 30].

14. Kinaesthetic study strategies. http://www.vark-

learn.com/english/page.asp?p=kinaestheticpr int [Last accessed on 2013 December 30].

15. Al-Saud LM. Learning style preferences of first-year dental students at King Saud University in Riyadh, Saudi Arabia: influence of gender and GPA. J Dent Educ. 2013;77:1371-1378.

16. Nuzhat A, Salem RO, Al Hamdan N, Ashour $\mathrm{N}$. Gender differences in learning styles and academic performance of medical students in Saudi Arabia. Med Teach. 2013;35 Suppl $1: \mathrm{S} 78-82$. 